\title{
Career Services Provision to Secondary School Students in Tanzania: Is it a dream or Reality?
}

\author{
Nkuba Mabula \\ Faculty of Education, Dar es salaam University College of Education, Tanzania \\ E-mail:nmabula@duce.ac.tz; Tel +255713359308
}

Accepted: March 22, 2012 Published: April 21, 2012

Doi:10.5296/ijld.v2i2.1674 URL: http://dx.doi.org/10.5296/ijld.v2i2.1674

\begin{abstract}
Career services provision include all actions which deal with giving students information and psychological assistance that may directly affect their decisions and choices which these individuals are about to make on their schooling and employment. The purpose of this study was to examine the status of career services provision and its role on career decision making among high school students in Dar es Salaam, Tanzania by comparing career services provision in government and international schools. Specifically, the study intended to identify the career programs available to students in schools, students' career knowledge and the contribution of career programs and career knowledge to students' career decision making. The study was conducted in six secondary schools using a sample of 322 students. The data from students were collected through a structured questionnaire and focus group discussions. The results revealed that students in international schools had access to many career programs and they have better knowledge on careers as compared to students in government schools. It was therefore concluded that, career services provision in international schools is to some degrees a reality as opposed to government schools where career services provision is still a dream. It is suggested that, future research can observe the role of career services provision in secondary schools to students' ability to make relevant course choices in higher learning institutions.
\end{abstract}

\section{INTRODUCTION}

Careers emerge to individuals through the interaction between an individual agency and the experience, constraining and enabling forces of the social context Kidd (2006). People's experience of careers over their life courses reflect their changing needs, values, aspiration and attitudes towards work. This situation has the role in employment related matters as linked to educational courses, the condition which reflects the need for career services provision in schools. Al-Samarrai and Bennell (2003) reported that increasing educational access across Africa has resulted in more qualified individuals chasing a limited number of jobs. This fact 
calls for serious career services provision in schools so as to provide career knowledge and career adjustment skills among school leavers. In any modern society, every individual makes a choice of career to pursue in life so as to meet physiological, biological, and social needs. This action promotes individual's emotional satisfaction and sense of belonging (Kimbrell and Vineyard, 1992). Kidd (2006) argues that, career services provision involves the provision of career skills and knowledge about work and educational choices. He explains further that, school leavers face many difficulties in career decision making due to inadequate career information, knowledge and skills. Focusing on the status of career services provision and career decision making among individuals in Africa, Biswalo (1996) reports that, inadequate career services available to youth have affected their ability to make informed career decision, a situation which has caused serious unemployment problems in the continent in recent years.

Tanzania as one of African countries face the same problem in its schools and learning institutions, the condition which forced the government to introduce career services as an integral part of the country's education system. In struggling to make career services provision a reality in Tanzania schools, all heads of secondary schools were argued to appoint school career counselors (masters or mistresses). These counselors were required to advise the heads of schools in matters related to applications for careers and training for students, assisting students with occupational information and their requirements. Furthermore, career counselors were required to help students in making long range plans of study so that they can apply to educational institutions where they can receive advanced training before joining the world of work (MOEC, 1997, P.20).

\section{Status of Career Programs and Students' Career Knowledge in Schools}

Adolescents are concerned about future work and occupations but are not sure which factors like money or prestige should influence one's choice for job. In fact, career information which is obtained at school through career programs can help many students to make right career decisions and pursue subject combinations which can lead them to their dreams (Kariuki, 2008). Santrock (1990) emphasizes that, exploration and planning play an important role in adolescent's career decision making.

It should be noted that, successful career services provision to students in schools, should involve career programs which can comprise the use of mass media, books, professional journals, internet, video, occupational flyers, career counselors, teachers and exposing students to role models (Hill \& Nathan, 2006). Generally the use of career programs such as internet programs, career visit, career workshops and other ways related to these can help students in getting career information available within and outside the country (Kingazi, 2006). Essentially, individuals need to understand what exists in the world of work so that they can examine the different career options available and decide their relevance to their personal characteristics. 
Ndambuki and Mutie (1999) emphasize that occupational information in terms of valid and usable data about different career options, positions, duties, entrance requirements, conditions of work, rewards offered, and advancement patterns are very crucial in career decision making. Explaining the importance of career knowledge and information, Parsons as cited in Sharf (1992) explains that, to select a career, an individual should ideally have information which indicates a clear understanding of himself/herself, his/her attitudes, abilities, interests, ambitions, resources, limitations, and their causes. Also an individual should have knowledge of the requirements and conditions for success, advantages and disadvantages, compensation, opportunities and prospects in different lines of work.

Moreover an individual should have a true reasoning on the relations of himself/herself and the requirements of success. Hoppock's argument also emphasize that, occupations are chosen to meet needs. But the decision making to this selection is guided by information and awareness about us, information and awareness about occupations and our knowledge about us and occupations. Therefore career knowledge and awareness are necessary in the process of career decision making so as to match job requirements with the personal characteristics and needs.

Intentions to perform a given behavior can be predicted from attitudes towards the behavior or behavioral process. It should be noted that attitudes, like other hypothetical constructs are not directly observable or measurable, their existence is inferred from a certain class of evaluative responses to the attitude object. Evaluating responses of behavioral type consists of the overt actions that people exhibit in relation to the attitude object it entails (Ajzen, 1991). Therefore, students' evaluation of career services provision in schools can be useful in suggesting their intention to participate and engaging in the available career services.

It has been further argued that people who evaluate an attitude object favorably tend to engage in behaviors that foster or support it, and people who evaluate an attitude object unfavorably tend to engage in behaviors that hinder or oppose it. Therefore it is true to the fact that, positive attitudes for students towards career services in schools can imply their good participation and use of the information obtained in different career activities while the opposite is true if there is negative attitude among students. Loan-Clarke (2005) in the study among 978 students intending to join nursing in the United Kingdom revealed attitude as the strongest predictor on the respondents intention to join nurse career $r=.59, \mathrm{p}<.01$.

\section{Statement of the Problem}

Studies conducted in Tanzania by different researchers such as Mugonzibwa, Kikwilu, Rugarabamu and Ntabaye (2000), Idd (2007) and Hezron (2008) focused on the factors which influence career choice among secondary school students. Hence, the part of career services provision in the country and its role on career decision making among students is not yet to be addressed. That is why this study sought to fill this gap by examining whether the career 
services provision in Tanzania schools is a dream or reality by examining career services provision in government and international schools.

\section{Objectives of the Study}

Specifically, the objectives of the study were to;

- Identify career programs available in schools and their contribution to students' career decision making in government and international schools.

- Assess students' knowledge in different career options in government and international schools.

- Examine the contribution of career knowledge to students' career decision in government and international schools.

\section{METHODOLOGY}

The study was carried out in six secondary schools in Dar es Salaam region which are Tambaza, Azania, Jangwani, Agakhan- mzizima, Laureate and Academic international. The study employed both quantitative and qualitative research approaches. The two approaches were used concurrently so as to minimize the weaknesses of each which would have been encountered if only one of them would be used. With quantitative approach, the cross sectional survey research design was used. The sample of the study included 322 students as indicated in Table 1.

Table 1: Number of Students by School

\begin{tabular}{l|lc}
\hline School & Expected respondents & Actual Respondents \\
& Frequenc & \\
& $(\%)$ & Frequency \\
\hline Tambaza & 70 & $\%$ \\
Jangwani & 21.7 & 70 \\
& 60 & 21.7 \\
Azania & 18.6 & 60 \\
Laureate & 60 & 18.6 \\
& 18.6 & 60 \\
Academic International & 60 & 18.6 \\
& 18.6 & 60 \\
Agakhan & 40 & 18.6 \\
& 12.4 & 40 \\
Total & 32 & 12.4 \\
& 9.9 & 32 \\
& 322 & 9.9 \\
\hline
\end{tabular}

Source: Field Data, February-March, 2009, Dar es salaam Region 
The questionnaire and focus group discussion were main tools used to gather information. Data obtained through questionnaires were coded and total scores by major sections or items representing various clusters were computed. Frequencies, descriptive statistics, t-test for independent samples, chi squire test through statistical package for the social sciences (SPSS) version 15.0 were employed in the analysis of data (Pallat, 2005). Moreover, the qualitative information obtained through focus group discussions was descriptively analyzed and a major summary was reported together with some direct quotations from respondents in providing more insight for explaining the findings of the study.

\section{RESULTS AND DISCUSSION}

\section{Status of Career Programs Available to Students in Schools}

Looking on career programs available to students in schools government and international schools students indicated variation in the availability of these services as indicated in table 2

Table 2: Status of Career Programs Available to Students in Government and International Schools

\begin{tabular}{|c|c|c|c|c|c|c|}
\hline $\begin{array}{l}\text { Career } \\
\text { programme }\end{array}$ & $\begin{array}{l}\text { Response } \\
\text { sampled } \\
\text { students }\end{array}$ & from & total & $\begin{array}{l}\text { Response from } \\
\text { International school }\end{array}$ & $\begin{array}{l}\text { government } \\
\text { students }\end{array}$ & and \\
\hline
\end{tabular}

\section{Total}

sampled students

( 322)

\begin{tabular}{|c|c|c|c|c|c|c|}
\hline & $\begin{array}{l}\text { Frequenc } \\
\mathrm{y}\end{array}$ & Percentage & Frequency & $\begin{array}{l}\text { Percen } \\
\mathrm{t}\end{array}$ & Frequency & $\begin{array}{l}\text { Percen } \\
\mathrm{t}\end{array}$ \\
\hline Career visit & 97 & 30.1 & 11 & 5.8 & 86 & 65.2 \\
\hline Career exhibition & 29 & 9.0 & 0 & 0 & 29 & 22 \\
\hline $\begin{array}{l}\text { Computer } \\
\text { internet }\end{array}$ & 115 & 35.7 & 1 & 0.5 & 114 & 86.4 \\
\hline $\begin{array}{l}\text { Career } \\
\text { counseling }\end{array}$ & 112 & 34.8 & 0 & 0 & 112 & 84.8 \\
\hline C/resource bank & 116 & 36 & 56 & 29.5 & 60 & 45.5 \\
\hline Career speakers & 129 & 40.1 & 25 & 13.2 & 104 & 78.8 \\
\hline Career clubs & 164 & 50.9 & 125 & 65.8 & 39 & 29.5 \\
\hline Career days & 86 & 26.7 & 3 & 1.6 & 83 & 62.9 \\
\hline $\begin{array}{l}\text { Other } \\
\text { programmes }\end{array}$ & 12 & 3.7 & 4 & 2.1 & 8 & 6.1 \\
\hline
\end{tabular}

Source: Field Data, February-March, 2009, Dar es salaam Region 
Considering the number of career programs offered in government and international schools, observations from the total sampled students reveal that, the provision of career services in schools is generally low.

This is evident from the responses by students in different schools. For example use of career exhibitions was identified by 29 respondents (9\%) followed by career days programs 86 respondents $(26.7 \%)$, career visits 97 respondents (30.1\%), career counseling 112 respondents (34.8\%), use of computer internet 115 respondents (35.7\%), use of career resource bank116 respondents $(36 \%)$, use of career speakers 129 respondents $(40.1 \%)$, and use of career clubs164 respondents $(50.9 \%)$, the only career program which was more practiced. When students were required to mention other career programs available in schools 12 respondents $(3.7 \%)$ mentioned career posters, magazines, career flyers, and video tapes as shown in Table 2 .

Practically, the generally low provision of career programs in Secondary schools was contributed much by government schools in the total sample as indicated in the results; this can be explained by various factors such as lack of career programs and information, absence of career instructional materials and career facilities. Biswalo (1996) when analyzing the situation of career guidance and counseling in Tanzania pointed out that, career services provision in many educational institutions in the country are ineffective, a situation which is linked to the lack of trained personnel in the field of career counseling.

Furthermore, the absence of guidelines for career services provision contributed to the failure in establishing effective career programs. This is because teachers were appointed to be career counselors without any training. In support of this observation Bailyn, as cited in Kidd (2006) argues that individuals' career emerge from the interaction between the individual agencies on the one hand and the experience, constraining and enabling forces of the social context on the other hand.

Therefore, with this situation where there is inadequate programs and trained career counseling in schools students will remain ignorance when it come to the matter of linking their school content and the world of work. Cobb (2001) and Santrock (2005) both emphasize in the argument that, with changes in technology, there are many careers added in the world of work for example army, farming, driving, teaching accountancy, banking, laws, engineering, clerical work and politics. Hence it is necessary for individuals to be made aware so as to help them in making informed career decision.

Comparing government and international schools, responses revealed that, many international school students were exposed to many career programs as compared to students in government schools. For example table 2 shows that 114 respondents (86.4\%) of students from international school identified more the internet to be the means of getting career information in their schools as compared to 1 respondent $(0.5 \%)$ from government schools. 
The differences between international and government schools were evident across other career programs including career counseling 112 respondent $(84.8 \%)$ and 0 respondent $(0 \%)$, use of career speakers 104 respondent $(78.8 \%)$ and 25 respondent (13.2\%), use of career visit 86 respondents $(65.2 \%)$ and 58 respondents $(11 \%)$, use of career days 83 respondent $(62.9 \%)$ and 3 respondent $(6 \%)$, use of career resource bank 60 respondents $(45.5 \%)$ and 56 respondents (29.5\%), career exhibitions 29 respondents (22\%) and 0 respondent $(0 \%)$, and other career programs 8 respondents $(6.1 \%)$ and 4 respondents $(2.1 \%)$ respectively.

The differences in the availability of career programs between international and government schools were tested to see if the observed difference is significant. The results from Chi-Square test was as indicated in table 3.

Table 3: Chi-Square Test for Government and International School Students to Show the Differences in Career Programmes Available in Schools.

\begin{tabular}{|c|c|c|c|c|}
\hline Career programme & $\begin{array}{l}\text { Continuity } \\
\text { value }\end{array}$ & correction & $D f$ & $\begin{array}{r}\text { Asymp. Sig. level } \\
(2 \text {-sided })\end{array}$ \\
\hline Career visit & 127.586 & & 1 & .000 \\
\hline Career exhibition & 43.232 & & 1 & .000 \\
\hline Computer internet & 246.234 & & 1 & .000 \\
\hline Career counseling & 243.466 & & 1 & .000 \\
\hline Career resource bank & 7.951 & & 1 & .000 \\
\hline Career speakers & 136.995 & & 1 & .000 \\
\hline Career clubs & 39.503 & & 1 & .000 \\
\hline Career days & 146.402 & & 1 & .000 \\
\hline $\begin{array}{l}\text { Other career } \\
\text { programmes }\end{array}$ & 2.383 & & 1 & .123 \\
\hline
\end{tabular}

Significance value is significant at $\alpha<.05$

Source: Field Data, February-March, 2009, Dar es Salaam Region

In the Chi- Square Test results obtained in Table 3, the continuity correction value is presented in association with the significant level in each career program identified. The continuity correction value compensates for the overestimate of the Chi-Square value and is presented in association with significant level labeled asymp.sig.(2-sided). Pallant (2005) pointed out that, to be significantly different for any tested variable in different two groups, the significant value obtained by Chi-Square test needs to be .05 or smaller than this value. Therefore in almost all career programs, the values are less than .05 , this means that there is a significant difference between government and international schools as regards to career programs availability. 
The low level of exposure to career programs among government school students might be attributed by less career information resources available to students in such schools as compared to international schools where there are trained counselors and many sources of career information. This situation was influenced by the availability of active career programs in international schools as opposed to government schools where career counselors are not trained (Biswalo, 1996).

Kingazi (2006) argues that, the sources of career information useful in schools for enabling effective career programs can include newspapers, radio, televising, magazines and other sources which are useful in disseminating information about joining various careers such as engineering, law and accounting. However career information might vary from one person to another and one context to another due to an individual's level of exposure and experience. During focus group discussions many students in government schools proved that, they were not aware of many career programs. One student from Jangwani secondary school which is one of the government schools made a comment that;

"We sometimes meet in career club at school and discuss different issues about subject selection and job choice. Our teachers normally provide answers to some of our problems but many of our doubts remain without answers. We real need information in how to match school studies and job choice".

This was opposite to the statement made by one student from Agakhan Mzizima international school who pointed out that;

"From the time we joined school we were given different opportunities to learn more about career choice in relation to our subject combinations. The school organized career talks with people from various occupations and our former school mates from various universities. We sometimes visit embassies, work places, participate in career exhibitions and discuss different issues with our career counselors on how to succeed in a career of interest".

The differences expressed by students on their involvement in career programs explains why international schools have more knowledge on various career options which can help them to make informed career decision as compared to the situation in government schools. The government school environment seems to have less career programs engagements such as planning for career visit, career days and career exhibitions opposite to this, administrators in international schools engage their students in various career activities such as career visits, inviting career speakers and career exhibition which contributed to their good ability in career identification. 
Franzoi (2000) argue that, for an individual to associate with a career source, they have to indicate their career interest and recognition gained through daily activities. Therefore, students in government schools might be having limited career awareness due to less career resources available in their school environments as opposed to the environment in international schools the condition which needs to be resolved.

\section{The Contribution of Career Programs Available in Schools to Students' Career Decision Making}

The study examined the extent to which career services offered at school contribute to students' career decision making. It was expected that good provision of career services would contribute to the student's ability in making informed career decision. However, findings were different as summarized in Table 4.

Table 4: Descriptive Statistics showing the contribution of career Programs in Career Decision making across Government and International School Students

\begin{tabular}{|c|c|c|c|c|c|c|c|c|c|}
\hline $\begin{array}{l}\text { Type of } \\
\text { school }\end{array}$ & $N$ & Min. & Median & Max. & Mean & $S d$ & $t$ & $d f$ & Sig. \\
\hline \multirow[t]{2}{*}{ Government } & 18 & & 12 & & 8.96 & 2.3 & -31.6 & 301.79 & .000 \\
\hline & 9 & 4 & & 20 & & & & & \\
\hline \multirow[t]{2}{*}{ International } & 13 & & 12 & & 16.92 & 2.08 & & & \\
\hline & 1 & 4 & & 20 & & & & & \\
\hline
\end{tabular}

Mean difference is significant at $p<.05$

Source: Field Data, February-March, 2009, Dar es salaam Region

Considering the results obtained from the students, the mean score calculated indicate that government school students score was $(\mathrm{M}=8.96, \mathrm{SD}=2.39)$, the value which is smaller than the median value (12). This result indicates that, the career services offered have low contribution on the students' career decision making process. However, data from international school students indicate a score of $(\mathrm{M}=16.92, \mathrm{SD}=2.08)$ which is greater than the median value (12) in the range of 4 to 20 . Results from the t-test shows that the difference is significant in the sense that scores for government school students was $(M=8.96, S D=2.3)$ and international school students was $[M=16.92, S D=2.3 ; t(301)=-31.6, p=.000]$. The magnitude of the differences in the mean scores between the two types of schools was large (eta squared $=.758$ ), which is 75.8 percent.

The differences in these findings can be explained by the reason that students in international schools are exposed to more career programs and various sources of career information and therefore have accumulated career experience and skills. Sharf (1992) and Ajzen (1991) argue that the accumulated career experiences from various sources of career information help an individual to define career intention and develop use of career opportunities while maintaining the use of career sources and experience in career decision making. Hence the use of different career programs together with teachers' guidance is important in schools so as to help students 
obtain career information and make informed career decisions. Contributing in the focus group discussion, one student from academic international secondary school argued that;

Career programs which are offered at our school are important in obtaining study opportunities and scholarships from various universities. Many of our school mates have obtained scholarships in international universities through career visits and other programs organized at school. We hope to do the same.

Likewise international school students have benefited more due to effective career programs and efforts from their career counselors in providing useful career information to students as compared to ineffective career programs and untrained career teachers in government schools. Kariuki (2008) points out that, career information attained through reliable social interaction with reliable sources attract individuals to benefit from them, this may enable students at school to make right career decisions. Due to this fact, the government schools in Tanzania need to make career services provision effective so as to help students acknowledge and use the available career services as the means for obtaining career information and career decision making. Hoppock as cited in Belkin (1975) emphasizes that, vocational development begins when we first become aware that a certain occupation can help us to meet our needs. Therefore in this context, vocational development progresses and occupational choice improves as we become better able to anticipate how well a prospective occupation will meet our needs.

\section{Students' Career Knowledge on Different Career Options}

Using descriptive statistics, career knowledge differences between students in international and government school students was assessed and the results indicated a difference in the level of career knowledge as indicated in Table 5.

T able 5: Descriptive statistics for Students' Career Knowledge and an Independent t- test across Government and International Students

\begin{tabular}{l|lllllc}
\hline Type of school & $N$ & Mean & $S D$ & $t$ & $d f$ & $\begin{array}{c}\text { Sig. } \\
\text { level }\end{array}$ \\
\hline Government & 183 & 28.88 & 6.76 & -11.03 & 193.84 & .000 \\
International & 132 & 41.37 & 11.67 & & & \\
\hline
\end{tabular}

Mean difference is significant at $p<.05$

Source: Field Data, February-March, 2009, Dar es Salaam Region

Field data indicate a large variation in mean scores for students' knowledge about different careers. The t-test shows that there was a significant difference in scores for government school students $(M=28.88, S D=6.76)$ and international school students $[M=41.37, S D=11.67 ; t(194)$ $=-11.03, p=.000]$. The magnitude of the differences in the mean scores between the two types of schools was large (eta squared $=.279$ ), which is 27.9 percent. The observed difference in career knowledge can be linked to the reasons that, Students in government schools depends more on the country education system guideline which is preparing individuals for the world of 
work without practical actions which focus in exposing students to various careers options. This is evident from the career provision which introduced in the country in 1997 which is less effective for school students.

In line to this observation, Biswalo (1996) explains that, the career services provision in many secondary schools in Tanzania is still less effective due to lack of trained career counselors, career instructional materials and related career facilities a factor which limits the knowledge of students on careers. Moreover the significant difference in the level of career knowledge between students in international and government schools can be reflected from the poor implementation of the objectives indicated in the policy after endorsing career services provision in secondary schools. The guideline for secondary school heads in Tanzania explain how well career services should be conducted in the country to help students in government schools in making career decision a reality. It emphasize that, every school in Tanzania should have career masters or career mistress who will be responsible in guiding students about career choice and supervising different career services (MOEC, 1997). During focus group discussion, one student from Agakhan Mzizima, secondary school which is one of the international schools included in the study explained that;

Our career counselor always gives us different career documents which help us in career decision making. We always meet once every week for discussion on how to match our personal attributes and careers of our interest. We know a lot of information about careers and criteria's for university selection and how to obtain scholarships both in local and international universities for courses of our interest.

Contributing in the same aspect during focus group discussion, one student from Azania secondary school, one of the government schools included in the study, explained a different situation as compared to what was narrated by a student from international school by insisting that;

In we don't know which courses are available in universities related with our current subject combinations. ... off course we have interest in some areas of work, example myself I like to do commerce but I don't know how which are good courses available at the university in this area.

Generally, the situation in government schools opposes what was suggested by Parson in the Trait and Factor theory. He proposes that, to select a career an individual should ideally have; first information which indicates a clear understanding of himself or herself, his or her attitudes, abilities, ambitions, resources, limitations, and their causes. Second an individual should have the knowledge of the requirements and conditions of success, advantages and disadvantages, compensation, opportunities and prospects in different lines of work. Moreover an individual should have a true reasoning on relations of himself or herself and the requirements of success (Parson, 1909) as cited in Sharf (1992). 
Hence more efforts are required so as to make career services provision a reality in Tanzania especially in government schools. This is possible by providing knowledge to students on careers available in the world of work and in matching these careers with personal attributes.

\section{The Contribution of Career Knowledge in Career Decision Making}

The contribution of career knowledge to students' career decision making was calculated. The descriptive statistics results showing the level of career knowledge contribution on career decision making were obtained as it can be seen in table 6 .

Table 6: Descriptive Statistics for Career Knowledge contribution on Subject Combination Choice across Government and International School Students

\begin{tabular}{|c|c|c|c|c|c|c|c|c|c|}
\hline $\begin{array}{l}\text { Type of } \\
\text { school }\end{array}$ & $N$ & Min & $\begin{array}{l}\text { Media } \\
n\end{array}$ & Max. & Mean & $S D$ & $T$ & $d f$ & Sig. \\
\hline $\begin{array}{l}\text { Governmen } \\
\mathrm{t}\end{array}$ & 189 & 4 & 12 & 20 & 11.94 & 3.99 & -15.58 & 289.81 & .000 \\
\hline $\begin{array}{l}\text { Internation } \\
\text { al }\end{array}$ & 132 & 4 & 12 & 20 & 17.17 & 1.95 & & & \\
\hline
\end{tabular}

Mean difference is significant at $p<.05$

Source: Field Data, February-March, 2009, Dar es salaam Region

Data in Table 6 suggests that, most of students from government schools were not sure if their current subject combination were selected using their own career knowledge. This fact was reflected by the score of ( $\mathrm{M}=11.94, \mathrm{SD}=3.99)$ which is very close to the median, the value which suggests that, subject combination choice which represent their career direction among government school students were more influenced by other factors such as social factors, relatives and parents' advice as explained during the focus group discussion.

However international school students agreed that, career knowledge obtained at school was the factor which contributed to their choice of subjects the fact which reflects their career decision making. This was evident with the score of $(M=17.17, \mathrm{SD}=1.95)$ which is greater than the median. Comparing the results between government and international school students on the contribution of students knowledge on subject combination choice, results from the t-test shows that, the is a significant difference at the score of $(M=11.94, S D=3.99)$ for government school students and [M=17.17, $S D=1.95 ; t(289)=-15.58, p=.000]$ for international school students. The magnitude of the differences in the mean scores between the two types of schools was large (eta squared $=.432$ ), which is 43.2 percent.

The differences observed in these findings can be associated with the reason that, career services provision in government schools are not giving students the adequate skills necessary for subject combination choice and career decision making in general. Kidd (2006) emphasizes that; career services provision is not just explanation about job choice rather the work and educational choices. This situation calls for more effort in providing necessary career skills and 
information for students in government schools so as to match their school studies and the careers of their interest as observed in international schools. During focus discussion, the majority of students in government schools showed that, they were not aware of works which their current subject combinations might lead them to. In support of this observation, one student at Tambaza High School specified that;

We are getting difficulties in matching the careers of our interest and our current subject combination. There is lack of guidance in our schools in how to match our career intention and subject choice. Anyway at this time we focus more on passing examinations, from there what to do will be determined.

Contrary to the situation in government schools, students in international school demonstrated good understanding of the relationship between their subject combinations and their aspired courses at the university as well as careers they intended to pursue after school. For instance one student at Academic International School explained that;

\begin{abstract}
"My interest is in medical studies, that is why I am doing physics, chemistry and biology combination. When I was in lower classes my interest was in law and medicines, but when I came to school my, counselor exposed me to different information's which helped me to make my decision in medical studies. I know the passes required in order to attain a scholarship both in local and oversee universities
\end{abstract}

The knowledge of careers which international school students have in relation to their subject combination choice and career decision making in general reflects the possibility that the career services offered in school have brought these individuals to a good level of exposure as opposed to the situation in government schools. Parson as cited in Sharf(1992) comment on the observed results by insisting that; to select a career, an individual should have information which indicates a clear understanding of himself or herself, his/her attitudes, abilities, interests, ambitions, resources, limitations and their causes. Also an individual should have knowledge of the requirements and conditions of success, advantages and disadvantages, compensation, opportunities and prospects in different lines of work and finally should be able reason on the relationship between an individual and the requirements of success. This situation calls for improving the career services in government schools as to provide reliable and adequate knowledge to students for matching their subject choice and careers of their interests.

\title{
Conclusions
}

This study has established new understanding about career services provision and its role on career decision making among high school students in Dar es Salaam, Tanzania. From the findings it can be concluded that, career service provision in government schools in the region 
is inadequate. This was evident in the fact that, the majority of high school students in government schools had less exposure to career programs and limited sources of career information. Moreover, students have low level of knowledge in career options available in the world of work the condition which force these students to use culture orientation and social influence in their process of career decision making.

The condition is different for international school students who demonstrated good exposure to various career programs and better knowledge in various career options. They also indicated the importance of career services provided in schools in their process of subject choice and career decision making in general. Therefore, these findings are unique to Dar es Salaam, Tanzania and call for government, education stakeholders and schools to improve career services provision in government schools through learning what international schools are doing.

\section{Recommendations}

This study found inadequate career services provision in government schools contrary with international schools where effective career services provision with many career programs such as use of internet, career workshops, career day, and presence of career day, career fliers and career visit was portrayed. From this observation it is recommended that;

- Government and educational institutions should collaborate so as to train school career counselors and providing career instructional materials so that career services provision can become a reality and not a dream as observed in government secondary schools.

- Furthermore, the government should establish properly coordinated career education services in collaboration with international schools where career services is to some degree is well organized and realistic.

- Findings from this study might have largely reflected career services provision to high school students in Dar es salaam, and since this study was based on cross sectional survey, it was difficult to reflect the effects of the observed issues. Therefore, a longitudinal study ranging from primary schools to colleges or university level would be essential so as to show in detail the causes and effects of inadequate career services provision in education institutions in the country. 


\section{REFERENCES}

Ajzen, I. (1991). The theory of planned behaviour: Organizational Behaviour and Human Decision processes, 50, 179-211.

Al-Samarrai, S. \& Bennell, P. (2003). Where has all the Education gone in Africa? Employment Outcomes among Secondary School Leavers. Brighton. UK. Institute of Sussex. From www.ids.ac.uk. Retrieved on $27^{\text {th }}$ January, 2009.

Belkin, S.G. (1981). Practical Counselling in the Schools. Lowa: Web group.

Biswalo, M.P. (1996). An Introduction to Guidance and counseling: In diverse African contexts. Dar es salaam: Dar es Salaam University Press.

Cobb, N.J. (2001). Adolescence (4 ${ }^{\text {th }}$ ed.): Continuity, Change, and Diversity. London: Mayfield Publishing Company.

Hezron, Z. (2008). Psychosocial Determinants of Career Choice Among Young People in Kuria Community. Unpublished M.A. Dissertation. University of Dar es Salaam.

Hill, L., \& Nathan, R. (2006). Career Counseling (2 ${ }^{\text {nd }}$ ed.). London: Sage Publications.

Idd, H. (2007). The Impact of Perceived Self - efficacy on Career Choice among Secondary School Students in Dar es Salaam. Unpublished M.A. Dissertation. University of Dar es Salaam.

Kariuki, K. (2008, April 6). An Easy to Read guide on Careers. Sunday Nation, p, 12.

Kidd, J. M. (2006). Understanding Career Counselling: Theory, research and practice. London: Sagr Publications.

Kimbrell, G., \& Vineyard, B. (1992). Suceeding in the World of Work (5 ${ }^{\text {th }}$ ed.). New York: McGraw-Hill.

Mugonzibwa, E.A., Kikwilu, E.N., Rugarabamu, P.N., \& Ntabaye, M.K. (2000).

Factors Influencing Career Choice among High school students in Tanzania. American Journal of Dental Education, 64 (6), 423-429.

MOEC. (1997). Kiongozi cha Mkuu wa Shule ya Secondary Tanzania. Dar es Salaam: Ministry of Education and Culture. 
Ndambuki, P.W., \& Muite, E. K. (1999). Guidance and Counselling in Schools and Colleges. Nairobi: Oxford University Press.

Pallant, J. (2005). SPSS Survival Manual ( $2^{\text {nd }}$ ed.): A step guide to data analysis using SPSS for windows (Version 12). New York: Open University Press.

Santrock, J. W. (2005). Adolescence (10 ${ }^{\text {th }}$ ed.). Boston: Mc-Graw Hill.

Sharf, R. S. (1992). Applying Career Development Theory to Counselling. California: Brooks/Cole Publishing Company. 